\title{
Studi Penggunaan Kombinasi Antipsikotik pada Pasien Skizofrenia di Rumah Sakit Yogyakarta
}

\author{
Anggie Indriani ${ }^{1}$, Wikan Ardiningrum ${ }^{2}$, Yosi Febrianti ${ }^{1, *}$ \\ ${ }^{1}$ Program Studi Farmasi, Jurusan Farmasi, Universitas Islam Indonesia, Yogyakarta 55524 \\ ${ }^{2}$ Rumah Sakit Grhasia, Yogyakarta 55524 \\ *Email korespondensi: yosi.febrianti@uii.ac.id
}

(Submit 15/03/2019, Revisi 05/09/2019, Diterima 20/12/2019)

\begin{abstract}
Abstrak
Skizofrenia merupakan gangguan jiwa berat yang memengaruhi pemikiran dan persepsi seseorang. Pemberian antipsikotik saat ini masih menjadi pengobatan primer untuk pasien skizofrenia. $10-30 \%$ pasien skizoprenia mendapatkan kombinasi antipsikotik karena respon yang tidak adekuat. Penelitian ini bertujuan untuk mengetahui pola dan profil efek samping dari penggunaan kombinasi antipsikotik pada pasien skizoprenia. Penelitian ini merupakan penelitian deskriptif-observasional dengan rancangan crosssectional (potong lintang). Pengumpulan data dilakukan secara retrospektif menggunakan data rekam medik. Pola penggunaan kombinasi antipsikotik pada pasien skizofrenia yaitu kombinasi antipsikotik yang paling banyak digunakan adalah kombinasi risperidon - klozapin sebanyak 43,4\%. Efek samping yang terjadi pada penggunaan kombinasi antipsikotik yaitu efek ekstrapiramidal yang berupa tremor, hipersalivasi, dan rigiditas sebanyak $15,2 \%$ pada penggunaan risperidon - klozapin. Kombinasi terbanyak yang sering digunakan pada pasien skizofrenia adalah kombinasi risperidon-klozapin, dan profil efek samping yang sering muncul dari penggunaan antipsikotik adalah efek ekstrapiramidal.
\end{abstract}

Kata kunci: Kombinasi Antipsikotik, klozapin, risperidon, skizofrenia

\section{Outline}

- Pendahuluan

- Metode

- Hasil dan Pembahasan

- Kesimpulan

- Ucapan Terima Kasih

- Pendanaan

- Konflik Kepentingan

- Daftar Pustaka

\section{Pendahuluan}

Skizofrenia merupakan gangguan jiwa berat yang ditandai oleh dua atau lebih tandatanda waham, halusinasi, pembicaraan kacau, emosi negatif seperti kehilangan ekspresi emosi. Gejala karakteristik dari skizofrenia menjangkau area disfungsi emosional, kognitif, dan perilaku, akan tetapi tidak ada gejala tunggal yang menjadi gejala utama dari skizofrenia ${ }^{1}$. Skizofrenia menyerah 21 juta jiwa di seluruh dunia ${ }^{2}$. 
Berdasarkan data riset kesehatan dasar (Riskesdas) tahun 2013, prevalensi gangguan jiwa berat di Indonesia, seperti skizofrenia dan gangguan psikosis lainnya mencapai 1,7 per 1.000 penduduk Persebaran prevalensi skizofrenia tertinggi salah satunya berada di Daerah Istimewa Yogyakarta sebanyak 2,7 per 1000 penduduk ${ }^{3}$. Secara rinci pada Daerah Istimewa Yogyakarta, jumlah tertinggi penderita skizofrenia berada di Kabupaten Kulonprogo 4,67\%, Kabupaten Bantul 4\%, Kota Yogyakarta 2,14\%, dan Kabupaten Gunungkidul 2,05\%. Sedangkan jumlah terendah ada di Kabupaten Sleman $1,52 \%{ }^{4}$.

Tingginya angka prevalensi skizofrenia, maka dibutuhkan manajemen terapi yang sesuai untuk pasien skizofrenia. Terapi farmakologi menggunakan antipsikotik yang terdiri dari 2 jenis yaitu antipsikotik golongan pertama (antipsikotik tipikal) dan antipsikotik golongan kedua (antipsikotik atipikal) ${ }^{5}$. Pada pengobatan skizofrenia terdapat dua pola pengobatan yaitu pengobatan tunggal dan kombinasi. Pedoman menyarankan kombinasi antipsikotik digunakan dalam keadaan tertentu saja, namun dalam praktek klinis menggabungkan dua atau lebih antipsikotik adalah hal yang sangat umum yaitu berkisar $10-30 \% 6$. Studi lain mengatakan bahwa kombinasi antipsikotik direkomendasikan kepada pasien yang gagal dengan pemberian antipsikotik monoterapi, termasuk clozapine ${ }^{7}$. Penggunaan kombinasi antipsikotik juga tidak disarankan karena dapat meningkatkan risiko beban efek samping, meningkatan interaksi obat, serta meningkatkan kesulitan bagi pasien agar tetap patuh pada rejimen pengobatan ${ }^{8}$. Efek samping yang sering terjadi pada pengobatan skizofrenia yaitu efek ekstrapiramidal. Extrapyramidal symptoms (EPS) termasuk gejala parkinsonism (yaitu kekakuan, tremor, dan bradikinesia), serta dystonia dan akathisia ${ }^{9}$.

Penelitian ini dilakukan untuk mengetahui pola peresepan kombinasi antipsikotik dan mengetahui kejadian efek samping pada peresepan antipsikotik pasien skizofrenia di RSJ Grhasia Yogyakarta pada tahun 2017. Penelitian ini dilakukan di Rumah Sakit Jiwa Grhasia Yogyakarta karena rumah sakit tersebut merupakan rumah sakit rujukan khusus menangani gangguan jiwa dan berada di Yogyakarta dengan prevalensi gangguan jiwa tinggi, sehingga diharapkan pasien skizofrenia di rumah sakit tersebut lebih banyak jika dibandingkan dengan rumah sakit umum lainnya.

\section{Metode}

Penelitian ini merupakan penelitian deskriptif non-eksperimental dengan rancangan cross-sectional yang dilakukan pada bulan Mei 2018 di RSJ Grhasia Yogyakarta. Proses pengambilan data dilakukan secara retrospektif menggunakan data rekam medik pasien yang di diagnosa skizofrenia oleh dokter spesialis kejiwaan dan mendapatkan peresepan antipsikotik kombinasi yang diresepkan oleh dokter spesialis kejiwaan di RSJ Grhasia Yogyakarta pada tahun 2017. Pasien skizofrenia yang tidak memiliki catatan rekam medik lengkap dan merupakan pasien rawat inap diekslusi dari penelitian. Penelitian ini telah disetujui oleh Komite Etik Fakultas Kedoteran Universitas Gadjah Mada dengan nomor KE/FK/0361/EC/2018.

Populasi pada penelitian ini adalah semua pasien skizofrenia di RSJ Grhasia Yogyakarta, dengan populasi terjangkau dalam penelitian ini adalah pasien rawat jalan yang terdiagnosa skizofrenia dan mendapatkan peresepan antipsikotik kombinasi yang diresepkan oleh dokter spesialis kejiwaan di RSJ Grhasia Yogyakarta pada tahun 2017. Sampel dalam penelitian ini merupakan bagian dari populasi terjangkau yang terpilih 
sebagai subjek yang akan diteliti sesuai kriteria inklusi. Sampel diambil dengan metode total sampling. Parameter yang diamati berupa karakteristik pasien skizofrenia, pola peresepan kombinasi antipsikotik, penggunaan obat selain antipsikotik dan kejadian efek samping pada pengobatan skizofrenia. Data karakteristik pasien yang dicatat adalah jenis kelamin, usia, status pendidikan, pekerjaan, status marital, riwayat keluarga, riwayat penggunaan narkotika, psikotripika, dan zat adiktif (NAPZA), riwayat kebiasaan merokok dan diagnosa pasien. Data pola peresepan kombinasi antipsikotik yang dicatat yaitu golongan serta jenis antipsikotik, dosis, dan durasi atau periode waktu penggunaan terapi antipsikotik pada pengobatan pasien skizofrenia. Data penggunaan obat selain antipsikotik dan data kejadian efek samping pada pengobatan skizofrenia. Data dianalisis dengan analisis univariate berupa ukuran statistik, yang disajikan dalam bentuk tabel.

\section{Hasil dan Pembahasan}

\section{A. Hasil}

Populasi pada penlitian ini sejumlah 244 pasien. Jumlah sampel yang terlibat sebanyak 99 pasien skizofrenia yang memenuhi kriteria inklusi. Karakteristik pasien dapat dilihat pada Tabel 1, pola peresepan kombinasi antipsikotik pada pengobatan skizofrenia tertera pada Tabel 2, kejadian efek samping pada Tabel 3, dan penggunaan selain antipsikotik pada Tabel 4.

Tabel 1 menunjukkan menunjukkan jumlah pasien laki-laki sebanyak 64 pasien (64,6\%) lebih banyak dibandingkan dengan pasien perempuan dengan usia yang paling banyak menderita skizofrenia pada pasien laki-laki yaitu usia 26-45 tahun sebanyak 47 pasien $(47,4 \%)$ dan pada pasien perempuan pada usia 26-45 tahun sebanyak 17 pasien $(17,2 \%)$. Tingkat pendidikan pasien yang paling banyak menderita skizofrenia adalah SLTA/SMK sebanyak 50 pasien (50,5\%). Pada status pekerjaan menunjukkan sebagian besar pasien skziofrenia yang tidak bekerja sebanyak 61 pasien $(61,6 \%)$. Status marital yanag paling banyak pada pasien yaitu tidak/belum menikah sebanyak 47 pasien $(47,5 \%)$. Pasien tanpa riwayat keluarga yang menderita gangguan jiwa lebih banyak 63 pasien $(63,6 \%)$ dibandingkan pasien yang memiliki riwayat keluarga menderita gangguan kejiwaan. Pada penggunaan NAPZA, pasien tanpa riwayat menggunakan NAPZA lebih tinggi yaitu sebanyak 94 pasien $(94,9 \%)$ dibandingkan pasien dengan riwayat pengguna NAPZA yaitu sebanyak 5 pasien $(5,1 \%)$. Hal yang sama pada riwayat kebiasaan merokok, yaitu pasien yang tidak merokok lebih besar yaitu 52 pasien $(52,5 \%)$. Mayoritas pasien skizofrenia di RSJ Grhasia Yogyakarta didiagnosa menderita skizofrenia paranoid (F20.0) sebanyak 83 orang $(83,8 \%)$.

Tabel 2 menunjukkan kombinasi antipsikotik yang paling banyak digunakan adalah kombinasi risperidone - clozapine sebanyak 43 pasien (43,4\%). Durasi penggunaan antipsikotik yang diberikan yaitu 1 bulan (30 hari) karena penelitian ini dilakukan pada pasien skizofrenia pada fase stabil/pemeliharan. Clozapine merupakan antipsikotik atipikal yang paling banyak diresepkan oleh dokter dengan dosis $25-50 \mathrm{mg} / \mathrm{hari}$ yaitu sebanyak 59 (26,94\%). Dosis anjuran penggunaan clozapine yaitu $150-600 \mathrm{mg} / \mathrm{hari}$, namun penggunaan clozapine dalam kisaran 25 - $50 \mathrm{mg} / \mathrm{hari}$ dapat digunakan untuk mendapatkan efek sedatif dibandingkan efek antipsikotik itu sendiri. Risperidone juga merupakan antipsikotik yang paling banyak diresepkan dengan dosis yang paling sering diberikan $4 \mathrm{mg} /$ hari yaitu sebanyak 60 (27,39\%). 
A. Indriani, dkk, Majalah Farmasetika, 4 (Suppl 1) 2019, 201 - 211

Tabel 1. Data Karakteristik Demografi Pasien Skizofrenia di RSJ Grhasia Yogyakarta Tahun 2017

\begin{tabular}{|c|c|c|}
\hline Karakteristik Pasien & Jumlah Pasien & Persentase (\%) \\
\hline \multicolumn{3}{|l|}{ Jenis Kelamin } \\
\hline Laki-Laki & 64 & 64,6 \\
\hline Perempuan & 35 & 35,4 \\
\hline \multicolumn{3}{|l|}{ Usia } \\
\hline \multicolumn{3}{|l|}{ Laki-laki } \\
\hline $12-25$ & 7 & 7,1 \\
\hline $26-45$ & 47 & 47,4 \\
\hline$>45$ & 10 & 10,1 \\
\hline \multicolumn{3}{|l|}{ Perempuan } \\
\hline $12-25$ & 4 & 4,1 \\
\hline $26-45$ & 17 & 17,2 \\
\hline$>45$ & 14 & 14,1 \\
\hline \multicolumn{3}{|l|}{ Pendidikan } \\
\hline Tidak Sekolah & 1 & 1 \\
\hline SD & 19 & 19,2 \\
\hline \multicolumn{3}{|l|}{ Pendidikan } \\
\hline SLTP & 22 & 22,2 \\
\hline SLTA/SMK & 50 & 50,5 \\
\hline DIII & 2 & 2 \\
\hline DIV & 1 & 1 \\
\hline S1 & 4 & 4,1 \\
\hline \multicolumn{3}{|l|}{ Pekerjaan } \\
\hline Pelajar & 1 & 1 \\
\hline Mahasiswa & 3 & 3 \\
\hline PNS & 1 & 1 \\
\hline Karyawan Swasta & 6 & 6,1 \\
\hline Wiraswasta & 10 & 10,1 \\
\hline Tani & 6 & 6,1 \\
\hline Buruh & 11 & 11,1 \\
\hline Tidak Bekerja & 61 & 61,6 \\
\hline \multicolumn{3}{|l|}{ Status Marital } \\
\hline Menikah & 44 & 44,4 \\
\hline Tidak/belum menikah & 47 & 47,5 \\
\hline Bercerai & 8 & 8,1 \\
\hline \multicolumn{3}{|l|}{ Riwayat Keluarga Skizofrenia } \\
\hline $\mathrm{Ya}$ & 36 & 36,4 \\
\hline Tidak & 63 & 63,6 \\
\hline \multicolumn{3}{|l|}{ Riwayat Penggunaan NAPZA } \\
\hline $\mathrm{Ya}$ & 5 & 5,1 \\
\hline Tidak & 94 & 94,9 \\
\hline \multicolumn{3}{|l|}{ Riwayat Kebiasaan Merokok } \\
\hline $\mathrm{Ya}$ & 47 & 47,5 \\
\hline Tidak & 52 & 52,5 \\
\hline \multicolumn{3}{|l|}{ Diagnosa } \\
\hline Tipe Pranoid (F20.0) & 83 & 83,8 \\
\hline Tipe Tak Terinci (F20.3) & 13 & 13,2 \\
\hline Tipe Residual (F20.5) & 3 & 3 \\
\hline
\end{tabular}


Tabel 2. Pola, Dosis, dan Durasi Penggunaan Kombinasi Antipsikotik pada Pengobatan Pasien Skizofrenia di RSJ Grhasia Yogyakarta Tahun 2017

\begin{tabular}{|c|c|c|c|c|c|}
\hline $\begin{array}{l}\text { Kombinasi } \\
\text { Antipsikotik }\end{array}$ & $\begin{array}{l}\text { Dosis Obat } \\
\text { Pertama } \\
\text { (mg/hari) }\end{array}$ & $\begin{array}{c}\text { Dosis Obat } \\
\text { Kedua } \\
\text { (mg/hari) }\end{array}$ & $\begin{array}{c}\text { Dosis Obat } \\
\text { Ketiga } \\
\text { (mg/hari) }\end{array}$ & $\begin{array}{l}\text { Durasi } \\
\text { (bulan) }\end{array}$ & $\begin{array}{c}\text { Jumlah } \\
\text { Pasien (\%) }\end{array}$ \\
\hline \multicolumn{6}{|l|}{ Atipikal-Atipikal } \\
\hline RPD - CLZ & \multirow[t]{2}{*}{$1-4 ; 1-4^{*}$} & $\begin{array}{c}10-200 ; 4- \\
50 *\end{array}$ & \multirow{3}{*}{ - } & 1 & $43(43,4)$ \\
\hline RPD - ARP & & \multirow{2}{*}{$\begin{array}{c}5 \\
10-200 ; 4- \\
50 *\end{array}$} & & 1 & $1(1)$ \\
\hline $\mathrm{OLZ}-\mathrm{CLZ}$ & $\begin{array}{c}4-10 ; 3- \\
10^{*}\end{array}$ & & & 1 & $5(5,1)$ \\
\hline \multicolumn{6}{|c|}{ Tipikal-Atipikal 2 kombinasi } \\
\hline $\mathrm{HLP}-\mathrm{CLZ}$ & $\begin{array}{c}1-10 ; 1,5- \\
10 *\end{array}$ & \multirow{3}{*}{$\begin{array}{c}10-200 ; 4- \\
50^{*} \\
1-4 ; 1-4^{*}\end{array}$} & \multirow{5}{*}{ - } & 1 & $18(18,2)$ \\
\hline HLP - RPD & & & & 1 & $4(4)$ \\
\hline CPZ - RPD & $25-200$ & & & 1 & $3(3)$ \\
\hline TFP - CLZ & $10 ; 10^{*}$ & \multirow{2}{*}{$\begin{array}{c}10-200 ; 4- \\
50 *\end{array}$} & & 1 & $3(3)$ \\
\hline FPZ - CLZ & $25 ; 25 *$ & & & 1 & $1(1)$ \\
\hline \multicolumn{6}{|l|}{3 kombinasi } \\
\hline RPD - CLZ - HLP & \multirow{6}{*}{$1-4$} & \multirow{4}{*}{$\begin{array}{c}10-200 ; 4- \\
50 *\end{array}$} & $\begin{array}{c}1-10 ; 1,5- \\
10 *\end{array}$ & 1 & $11(11,1)$ \\
\hline RPD - CLZ - FPZ & & & $25 ; 25^{*}$ & 1 & $5(5,1)$ \\
\hline RPD - CLZ - TFP & & & 10 & 1 & $1(1)$ \\
\hline RPD - CLZ - CPZ & & & $25-200$ & 1 & $1(1)$ \\
\hline RPD - CPZ - FPZ & & $25-200$ & \multirow[b]{2}{*}{$25 ; 25^{*}$} & 1 & $1(1)$ \\
\hline RPD - HLP - FPZ & & $\begin{array}{c}1-10 ; 1,5- \\
10^{*}\end{array}$ & & 1 & $1(1)$ \\
\hline CLZ - OLZ - HLP & $\begin{array}{c}10-200 ; 4- \\
50 *\end{array}$ & $\begin{array}{c}4-10 ; 3- \\
10^{*}\end{array}$ & $\begin{array}{c}1-10 ; 1,5- \\
10^{*}\end{array}$ & 1 & $1(1)$ \\
\hline & & Total & & & $99(100)$ \\
\hline
\end{tabular}

Keterangan:

* $\quad=$ Penggunaan dosis pada usia lanjut ( $>45$ tahun)
HLP $=$ Haloperidol
$\mathrm{RPD}=$ Risperidone
$\mathrm{CPZ}=$ Chlorpromazine
CLZ = Clozapine
TFP = Trifluoperazine
OLZ = Olanzapine
$\mathrm{FPZ}=$ Fluphenazine decanoate $\mathrm{ARP}=$ Aripiprazole

Tabel 3 menunjukkan kombinasi antipsikotik yang paling banyak memicu resiko efek samping adalah kombinasi antara risperidone - clozapine sebanyak 15 pasien (15,2\%); clozapine - haloperidol sebanyak 4 pasien (4\%); dan risperidone - haloperidol sebanyak 3 pasien (3\%). Keseluruhan efek samping yang terjadi pada setiap penggunaan obat antipsikotik kombinasi ini, yang paling sering muncul adalah sindrom ekstrapiramidal (tremor, hipersalivasi, dan rigiditas). Obat yang dapat mengatasi efek samping pada penggunaan antipsikotik yaitu triheksifenidil dapat dilihat pada tabel 4 , bahwa penggunaan triheksifenidil merupakan terapi adjuvan yang paling sering diresepkan bersamaan dengan penggunaan antipsikotik sebanyak sebanyak 88 pasien $(88,9 \%)$.

\section{B. Pembahasan}

Hasil penelitian menunjukkan jumlah pasien laki-laki lebih banyak dibandingkan dengan pasien perempuan. Prognosis pada laki-laki lebih buruk dibandingkan pada penderita perempuan, dikarenakan adanya pengaruh antidopaminergik estrogen yang dimiliki oleh perempuan. Estrogen memiliki efek pada aktivitas dopamin di nukleus akumben dengan cara menghambat pelepasan dopamin. Peningkatan jumlah reseptor dopamin 
di nukleus kaudatus, akumben, dan putamen merupakan etiologi penyebab terjadinya skizofrenia. Akibat adanya efek perlindungan atau neuroprotektif dari hormon estrogen ini secara tidak langsung akan mempengaruhi perjalanan penyakit skizofrenia yang lebih baik pada perempuan ${ }^{10}$.

Tabel 3. Efek Samping yang Muncul pada Pasien Skizofrenia di RSJ Grhasia Yogyakarta Tahun 2017

\begin{tabular}{|c|c|c|c|}
\hline Kombinasi Antipsikotik & Efek Samping Obat & Jumlah & Persentase (\%) \\
\hline \multicolumn{4}{|l|}{ Atipikal-Atipikal } \\
\hline \multirow[t]{5}{*}{ RPD - CLZ } & Tremor & 11 & 11,1 \\
\hline & Hipersalivasi & 1 & 1 \\
\hline & Rigiditas & 2 & 2 \\
\hline & Tremor, rigiditas & 1 & 1 \\
\hline & Total & 15 & 15,2 \\
\hline \multirow[t]{3}{*}{ CLZ - OLZ } & Tremor & 1 & 1 \\
\hline & Tremor, hipersalivasi, rigiditas & 1 & 1 \\
\hline & Total & 2 & 2 \\
\hline RPD - ARP & - & 0 & 0 \\
\hline \multicolumn{4}{|l|}{ Tipikal+Atipikal } \\
\hline \multicolumn{4}{|l|}{2 kombinasi } \\
\hline CLZ - HLP & Tremor & 4 & 4 \\
\hline RPD - HLP & Tremor & 3 & 3 \\
\hline RPD - CPZ & Tremor & 1 & 1 \\
\hline CLZ - TFP & - & 0 & 0 \\
\hline CLZ - FPZ & - & 0 & 0 \\
\hline \multicolumn{4}{|l|}{3 kombinasi } \\
\hline RPD - CLZ - HLP & Tremor & 2 & 2 \\
\hline RPD - CLZ - FPZ & - & 0 & 0 \\
\hline \multicolumn{4}{|l|}{3 kombinasi } \\
\hline RPD - CLZ - TFP & - & 0 & 0 \\
\hline RPD - CLZ - CPZ & - & 0 & 0 \\
\hline RPD - CPZ - FPZ & - & 0 & 0 \\
\hline RPD - HLP - FPZ & Tremor & 1 & 1 \\
\hline \multirow[t]{2}{*}{ HLP - CLZ- OLZ } & Hipersalivasi & 1 & 1 \\
\hline & Total & 29 & 29,1 \\
\hline
\end{tabular}

Keterangan:

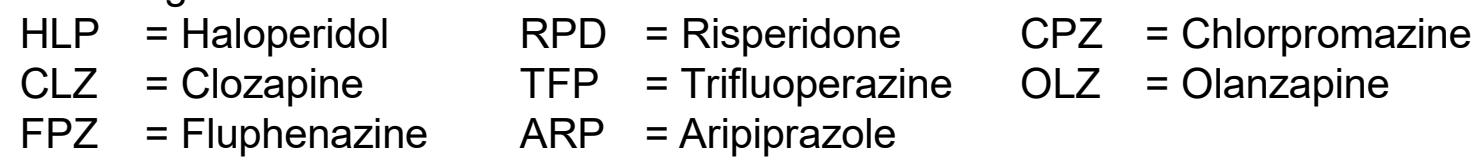

Tabel 4. Penggunaan Obat Selain Antipsikotik pada Pasien Skizofrenia di RSJ Grhasia Yogyakarta Tahun 2017

\begin{tabular}{|l|l|c|c|c|}
\hline Golongan & Nama Obat & Dosis (mg/hari) & Jumlah & Persentase \\
\hline Antikolinergik & Trihexyphenidyl & 4 & 88 & 88,9 \\
\hline Antikonvulsan & Natrium divalproat & 250 & 4 & 4 \\
\hline & Phenytoin & 200 & 1 & 1 \\
\hline Antidepresan & Fluoxetine & $25 ; 40$ & 3 & 3 \\
\hline & Amitriptyline & $25 ; 50$ & 2 & 2 \\
\hline & Sertraline & 50 & 1 & 1 \\
\hline Antihipertensi & Captopril & 12,5 & 1 & 1 \\
\hline & Valsartan & 40 & 1 & 1 \\
\hline Antidiabetes & Metformin & 500 & 1 & 1 \\
\hline Antidislipidemia & Simvastatin & 10 & 1 & 1 \\
\hline Ansiolitik & Lorazepam & 1 & 1 & 1 \\
\hline
\end{tabular}


Berdasarkan tingkat pendidikan pasien yang paling banyak menderita skizofrenia adalah dalam tingkat SLTA/SMK. Salah satu gejala skizofrenia yaitu gejala kognitif, dimana gejala kognitif ditandai dengan kurangnya kemampuan untuk memahami informasi dan menggunakannya untuk membuat keputusan, kesulitan dalam fokus atau perhatian, bermasalah dengan fungsi memori dan tidak mampu menggunakan informasi. Sehingga pasien skizofrenia cenderung tidak bisa mendapatkan pendidikan yang lebih tinggi lagi karena kesulitan untuk mengikuti pendidikan formal ${ }^{11}$.

Pada status pekerjaan menunjukkan sebagian besar pasien skziofrenia yang tidak bekerja. Kurangnya motivasi telah lama dikenal sebagai mediator yang signifikan dalam hubungan antara kognisi dan keterampilan seperti kemampuan untuk mengelola keuangan secara mandiri atau mencari pekerjaan ${ }^{12}$. Pelatihan keterampilan sosial perlu diberikan karena sebagai salah satu kegiatan pembelajaran yang memungkinkan pasien memperoleh keterampilan yang diperlukan untuk memenuhi tuntutan interpersonal, perawatan diri dan menghadapi kehidupan masyarakat dimana tujuan dari pelatihan keterampilan sosial adalah untuk memperbaiki kekurangan tertentu dalam fungsi sosial pasien ${ }^{13}$.

Hasil pada status marital pasien skizofrenia menunjukkan pasien yang tidak/belum menikah lebih banyak dari pasien yang menikah ataupun yang bercerai. Pada gangguan skizofrenia kebanyakan penderita akan mengalami kesulitan untuk beradaptasi di masyarakat terutama untuk berhubungan dengan orang lain. Penderita cenderung tidak membangun atau mempertahankan hubungan yang signifikan, sehingga banyak penderita skizofrenia yang tidak menikah atau mempunyai anak ${ }^{14}$.

Berdasarkan riwayat keluarga, hasil penelitian pasien tidak memiliki riwayat keluarga yang menderita gangguan jiwa lebih banyak dibandingkan dengan pasien dengan riwayat keluarga yang menderita gangguan jiwa. Faktor yang kemungkinan besar menjadi pemicu terjadinya skizofrenia pada seseorang salah satunya adalah faktor genetik. Namun faktor lingkungan dan sosial mungkin juga berperan dalam pengembangan skizofrenia. Tekanan lingkungan yang terkait dengan skizofrenia meliputi trauma masa kecil, etnis minoritas, tinggal di daerah perkotaan, dan isolasi sosial. Stres sosial seperti diskriminasi atau kesulitan ekonomi juga dapat menyebabkan individu mengalami pemikiran delusi atau paranoid ${ }^{15}$.

Pada riwayat penggunaan NAPZA hasil penelitian menunjukkan pasien skizofrenia sebagian besar tidak memiliki riwayat penggunaan NAPZA. Penyalahgunaan NAPZA dapat menyebabkan munculnya gejala psikotik diantaranya halusinasi dan waham. NAPZA dapat menimbulkan kecanduan sehingga para pengguna akan mengkonsumsinya secara terus-menerus yang akan mempengaruhi susunan saraf pusat sehingga menimbulkan gangguan jiwa pada pengguna NAPZA. Sehingga penggunaan NAPZA di masa lalu sebagai salah satu faktor yang dapat menyebabkan terjadinya penyakit skizofrenia ${ }^{16}$.

Berdasarkan riwayat kebiasaan merokok didapatkan hasil bahwa pasien yang tidak merokok lebih besar dibandingkan pasien yang memiliki kebiasaan merokok. Nikotin yang terkandung dalam rokok memiliki kemampuan untuk meningkatkan level dopamin. Peningkatan dopamin memberi dampak gejala positif yang semakin berat ${ }^{17}$. Nikotin dapat mengatasi gejala negatif seperti anhedonia dan penarikan sosial karena 
kemampuan nikotin untuk meningkatkan level dopamin pada nucleus accumbens dan korteks prefrontal, serta adanya peningkatan pada sistem reward dari nikotin yang memberikan perasaan rileks dan bahagia. Sehingga individu dengan skizofrenia menggunakan rokok sebagai cara untuk menghilangkan gejala depresif dan psikotik mereka. Merokok juga mempengaruhi metabolisme dan kadar obat-obatan psikiatri dalam darah yaitu clozapine, olanzapine, dan haloperidol ${ }^{18}$. Hal ini disebabkan oleh induksi enzim polycyclic aromatic carbohydrates yang diproduksi ketika tembakau dibakar. Enzim ini kemudian akan menginduksi cytochrome P450 1A2 (CYP1A2) dan glucoronosyltransferase (UGT) yang berguna dalam metabolisme ketiga obat antipsikotik tersebut dimana ketiga obat antipsikotik tersebut dimetabolisme salah satunya melalui enzim CYP1A2. Enzim ini dapat menurunkan level ketiga antipsikotik tersebut dalam plasma sampai sepertiga dosisnya. Berkurangnya level obat antipsikotik tersebut dalam plasma menyebabkan pasien memerlukan dosis pengobatan yang lebih tinggi untuk mendapatkan efek yang diinginkan ${ }^{19}$.

Subtipe skizofrenia yang paling banyak diderita adalah skizofrenia tipe paranoid. Skizofrenia paranoid dianggap sebagai subtipe paling umum dari gangguan kronis ini ${ }^{20}$. Tipe paranoid ditandai dengan adanya delusi dan halusinasi, tetapi tidak ada gangguan pemikiran, perilaku yang tidak teratur, dan respon yang datar ${ }^{13}$.

Kombinasi antipsikotik yang paling banyak digunakan adalah kombinasi risperidone clozapine. Kombinasi clozapine - risperidone efektif digunakan pada pasien yang resisten karena clozapine memiliki kemampuan menduduki reseptor D2 (16\% sampai $68 \%$ ) sedangkan risperidone (63\% sampai $89 \%$ ), sehingga dengan penambahan risperidone diharapkan mampu meningkatkan respon pasien terhadap clozapin ${ }^{21}$. Clozapine adalah antipsikotik generasi kedua yang termasuk kelas dibenzodiazepine, merupakan neuroleptik atipikal dengan afinitas tinggi untuk reseptor dopamin D4 dan afinitas rendah untuk subtipe lain, antagonis di alpha- adrenoseptor, reseptor 5-HT2A, reseptor muskarinik, dan reseptor histamin $\mathrm{H} 1$. Clozapine bekerja dengan menduduki reseptor D2 hanya sekitar 38\%-48\%. Bahkan dengan dosis setinggi $900 \mathrm{mg}$ sehari, kurang dari $50 \%$ dari reseptor D2 ditempati22.

Dosis anjuran penggunaan clozapine yaitu $150-600 \mathrm{mg} / \mathrm{hari}^{23}$. Pada penelitian ini clozapine yang paling banyak digunakan dengan dosis $25-50 \mathrm{mg} / \mathrm{hari}$ yaitu sebanyak 59 (26,94\%). Penggunaan clozapine dalam kisaran 25 - 50 mg untuk mendapatkan efek sedatif dibandingkan efek antipsikotik itu sendiri ${ }^{24}$. Risperidone merupakan derivat dari benzisoxazole dengan afinitas terhadap reseptor serotonin 5-HT2 dan dopamin D2 dan beberapa afinitas terhadap reseptor alfa-adrenergik, histamin $\mathrm{H} 2$, dan dopamin D1. Risperidone memiliki afinitas yang lebih tinggi terhadap reseptor dopamin D2 daripada clozapine. Risperidone diindikasikan untuk terapi skizofrenia baik untuk gejala negatif maupun positif ${ }^{25}$. Dosis anjuran penggunaan risperidone yaitu $2-8 \mathrm{mg} / \mathrm{hari}^{23}$. Pada penelitian ini risperidone yang paling banyak digunakan dengan dosis $4 \mathrm{mg} / \mathrm{hari}$ yaitu sebanyak 60 (27,39\%). Risperidone dosis rendah 2 - 5 mg/hari, D2 mengikat berkisar antara $60 \%$ hingga $79 \%$, tetapi dengan dosis lebih besar dari $6 \mathrm{mg}$ setiap hari, pengikatan umumnya melebihi ambang $77 \%$ yang terkait dengan perkembangan EPS. Risperidone $2 \mathrm{mg} / \mathrm{hari}$ menghasilkan ikatan 5-HT 2A lebih besar dari $70 \%$, dan dengan $4 \mathrm{mg} /$ hari hampir $100 \%^{26}$. 
Durasi penggunaan antipsikotik yang diberikan pada penelitian ini yaitu 1 bulan (30 hari). Hal ini sesuai dengan durasi tatalaksana terapi fase stabil/pemeliharan. Pada fase ini penggunaan obat umumnya dilakukan selama 4-6 minggu. Tujuan dari terapi pemeliharaan selama fase stabil adalah untuk memastikan bahwa kesembuhan terpelihara dan meningkatkan kualitas hidup pasien skizofrenia. Pasien yang bermasalah dalam kepatuhan minum obat dapat menggunakan bentuk sediaan depot, yang berupa injeksi intramuskular yang dapat diberikan dalam interval 2-4 minggu, seperti fluphenazine decanoate atau haloperidol decanoate ${ }^{13}$.

Kombinasi antipsikotik yang paling banyak memicu resiko efek samping adalah kombinasi antara risperidone - clozapine. risperidone memiliki risiko EPS yang sedang (moderate). Frekuensi EPS dan kebutuhan antikolinergik berkurang hingga $40 \%$ dibandingkan dengan antipsikotik generasi pertama. Ada delapan laporan kasus rabbit syndrome yang diinduksi risperidone. Sedangkan risiko pasien yang menggunakan clozapine menunjukkan adanya gangguan gerakan dan hipersalivasi (mempengaruhi $\geq 50 \%$ pasien $)^{9}$. Efek samping yang terjadi dapat dipengaruhi oleh beberapa faktor antara lain perbedaan individu dalam mentoleransi efek samping dari setiap obat, semakin banyak kombinasi yang digunakan maka semakin besar pula kemungkinan terjadinya resiko efek samping, efek samping yang terjadi berdasarkan kekuatan afinitas pada setiap reseptor yang diduduki dari masing-masing obat yang dikombinasikan. Golongan obat lain juga ditambahkan bersamaan dengan antipsikotik pada terapi pengobatan skizofrenia, sehingga ada kemungkinan efek samping yang terjadi disebabkan oleh penggunaan obat lain dan lebih meningkatkan potensi terjadinya efek samping ${ }^{10}$.

Pengobatan dengan psikoaktif lain biasanya ditambahkan pada pengobatan fase akut untuk mengobati kondisi komorbid pasien atau gejala-gejala lain yang terkait, seperti agitasi, agresi, dan gejala afektif, untuk meringankan gangguan tidur dan untuk mengatasi efek samping karena penggunaan antipsikotik ${ }^{27}$. Terapi tambahan yang paling banyak diberikan merupakan antiparkinson yaitu triheksifenidil (THP) Triheksifenidil merupakan obat antikolinergik yang banyak digunakan untuk mengatasi EPS. THP yang merupakan senyawa piperidin yang memiliki daya antikolinergik dan efek sentralnya mirip atropin namun lebih lemah, bekerja dengan cara mengurangi aktivitas kolinergik di kaudatus dan puntamen yaitu dengan memblok reseptor asetilkolin ${ }^{28}$.

\section{Kesimpulan}

Pola penggunaan kombinasi antipsikotik pada pasien skizofrenia di Rumah Sakit Jiwa Grhasia Yogyakarta pada tahun 2017 yaitu kombinasi antipsikotik yang paling banyak digunakan adalah kombinasi risperidone - clozapine sebanyak 43,4\%. Efek samping yang terjadi pada penggunaan kombinasi antipsikotik yaitu efek ekstrapiramidal yang berupa tremor, hipersalivasi, dan rigiditas sebanyak $15,2 \%$ pada penggunaan risperidone - clozapine.

\section{Ucapan Terima Kasih}

Terima kasih kepada pihak yang memberikan kontribusi terhadap penelitian ini, yakni instalasi rekam medik RSJ Grhasia Yogyakarta. 


\section{Pendanaan}

Penelitian ini tidak didanai oleh sumber hibah manapun.

\section{Konflik Kepentingan}

Tidak terdapat potensi konflik kepentingan dengan penelitian, kepenulisan (authorship), dan atau publikasi artikel ini.

\section{Daftar Pustaka}

1. American Psychiatric Association. Diagnostic and Statistical Manual of Mental Disorders. Arlington (2013). doi:10.1176/appi.books.9780890425596.744053

2. World Health Organization. Schizophrenia. (2016). Available at: http://www.who.int/mediacentre/factsheets/fs397/en/. (Accessed: 15th October 2017)

3. Badan Penelitian dan Pengembangan Kesehatan. Riset Kesehatan Dasar (RISKESDAS) 2013. Lap. Nas. 2013 1-384 (2013). doi:1 Desember 2013

4. National Geographic Indonesia. Jumlah Penderita Skizofrenia di Yogyakarta Tertinggi Kedua Nasional. (2016). Available at: http://nationalgeographic.grid.id/read/13306122/jumlah-penderita-skizofrenia-diyogyakarta-tertinggi-kedua-nasional?page=all. (Accessed: 15th October 2017)

5. Morrison, A. P. et al. Cognitive Therapy For People With Schizophrenia Spectrum Disorders Not Taking Antipsychotic Drugs: A Single-Blind Randomised Controlled Trial. Lancet 383, 1395-1403 (2014).

6. Gallego, J. A., Nielsen, J., De Hert, M., Kane, J. M. \& Correll, C. U. Safety And Tolerability Of Antipsychotic Polypharmacy. Expert Opin. Drug Saf. 11, 527-542 (2012).

7. Fleischhacker, W. W. \& Uchida, H. Critical Review Of Antipsychotic Polypharmacy In The Treatment Of Schizophrenia. Int. J. Neuropsychopharmacol. 17, 10831093 (2014).

8. Lally, J. \& Maccabe, J. H. Antipsychotic Medication In Schizophrenia: A Review. 169-179 (2015). doi:10.1093/bmb/ldv017

9. Gardner, D. M. . \& Teehan, M. D. Antipsychotics and their Side Effects. (United States of America by Cambridge University Press, 2011).

10. Yulianty, M. D., Cahaya, N. \& Srikartika, V. M. Studi Penggunaan Antipsikotik dan Efek Samping pada Pasien Skizofrenia di Rumah Sakit Jiwa Sambang Lihum Kalimantan Selatan. 3, 153-164 (2017).

11. National Institute of Mental Health. Schizophrenia. (2016). Available at: https://www.nimh.nih.gov/health/topics/schizophrenia/index.shtml. (Accessed: 23rd August 2018)

12. Kremen, L. C., Fiszdon, J. M., Kurtz, M. M., Silverstein, S. M. \& Choi, J. Intrinsic and Extrinsic Motivation and Learning in Schizophrenia. 144-153 (2016). doi:10.1007/s40473-016-0078-1

13. Ikawati, Z. Farmakoterapi Penyakit Sistem Saraf Pusat. (Bursa IImu, 2011).

14. Durand, V. M. \& Barlow, D. H. Intisari Psikologi Abnormal. (Pustaka Pelajar, 2007).

15. Ayano, G. Schizophrenia: A Concise Overview of Etiology, Epidemiology Diagnosis and Management: Review of literatures. J. Schizophr. Res. 3, 1026 (2016).

16. Yeni, O. \& Fitriah, N. Kejadian Gangguan Jiwa Di Ruangan Poliklinik Napza Terpadu Di Rumah Sakit Dr . Ernaldi Bahar Provinsi Sumatera Selatan. 5, 57-62 (2014). 
17. Kurniasih, P. T. \& Saragih, J. The Relationship Between Smoking Degrees With Schizophrenic Patients Behavior Changing At Aceh Mental Hospital. 2, 1-6 (2017).

18. Kumari, V. \& Postma, P. Nicotine Use in Schizophrenia: The Self Medication Hypotheses. 29, 1021-1034 (2005).

19. Hukkanen, J., lii, P. J., Peng, M., Dempsey, D. \& Benowitz, N. L. Letter to the Editors Effect of nicotine on cytochrome P450 1A2 activity. 10-12 (2011). doi:10.1111/j.1365-2125.2011.04023.x

20. PSYCOM. Paranoid Schizophrenia. (2018). Available at: https://www.psycom.net/paranoid-schizophrenia. (Accessed: 8th July 2018)

21. Gibson, A. P. ., Patel, N. C. ., Lauriello, J. \& Buckley, P. F. Antipsychotic combinations Blind step or logical ? Though unsupported by evidence, using $>1$ antipsychotic may make sense for some treatment-resistant patients. 7, 41-53 (2008).

22. Wells, B. G., DiPiro, J. T., Matzke, G. R. \& Posey, L. M. Pharmacotherapy Handbook (7th Edition). (McGraw-Hill Professional Publishing, 2009).

23. PDSKJI. Pedoman Nasional Pelayanan Kedokteran ( PNPK ) Jiwa / Psikiatri. (2012).

24. Natari, R. B., Sukandar, E. Y. \& Sigit, J. I. Antipsychotic Use Evaluation on First Episode Schizophrenic Patients at Jambi Psychiatric Hospital. XXXVII, 159-165 (2012).

25. Mangarell, L. B. . \& Martinez, J. M. CONCISE GUIDE TO Psychopharmacology. (American Psychiatric Publishing, 2006).

26. Wells, B. G., DiPiro, J. T., Matzke, G. R. \& Posey, L. M. Pharmacotherapy Handbook 8th edition. (McGraw-Hill Professional Publishing, 2012).

27. Dixon, L. B. \& Perkins, D. O. Treatment of Patients With Schizophrenia Second Edition. (2010).

28. Rahaya, A. \& Cahaya, N. Study Of The Trihexyfenidil Use Inpatients Schizophrenia 'S Receiving Antipsychotic Therapy At Sambang Lihum HospitalSouth Borneo. 2, 124-131 (2016). 